\title{
Preface
}

\section{"Holocene changes in environment and climate in the central Mediterranean as reflected by lake and marine records"}

\author{
M. Magny ${ }^{1}$ and N. Combourieu Nebout ${ }^{2}$ \\ ${ }^{1}$ CNRS - UMR6249, Laboratoire Chrono-Environnement, UFR des Sciences et Techniques, 16 Route de Gray, \\ 25030 Besançon, France \\ ${ }^{2}$ CNRS - UMR8212, LSCE - Gif-sur-Yvette, Gif-sur-Yvette, France \\ Correspondence to: M. Magny (michel.magny@univ-fcomte.fr)
}

Presently considered one of the hot-spots of world biodiversity, the Mediterranean region will probably be largely impacted by the ongoing climate change and thus is of major interest for palaeoenvironmental and palaeoclimatic research.

- At the interface between the European temperate and the African tropical zones, the Mediterranean appears to be very sensitive to changes in the hydrological cycle and water resources. Its pronounced precipitation seasonality represents the main climate constraint for the Mediterreanean ecosystems and societies. In the perspective of ongoing global change (Solomon et al., 2007), there is an urgent need for a better understanding of climatic change and its associated environmental variations around the Mediterranean basin.

- Already exposed to natural (latitudinal and climatic) factors, the fragile Mediterranean ecosystems has been affected by an early and strong human impact. In fact, the Mediterranean may be considered one of the cradles of mankind with an early expansion of Neolithic agricultural societies which included the Iberian peninsula as early as 7500-7000 cal BP (Pérez-Obiol et al., 2011); this early expansion was followed by the development of brilliant civilisations before Christian era in the Near East (Mesopotomia), in Egypt, Crete, Greece and Italy. At present, the Mediterranean area is undergoing strong human pressure due to a general population growth greatly influenced in the warm season by the tourism.
In this general context, several of special journal issues have been dedicated to the environmental and climatic changes in the Mediterranean during the Holocene, dealing with the whole Mediterranean (e.g. Zolitschka et al., 2000; Roberts et al., 2001, 2011; Pinardi and Masetti, 2000), or only a part of the Mediterranean basin (e.g. Catto, 2005; Oldfield, 1996; Roberts et al., 1999), referring to multiproxy/terrestrial-marine approaches (e.g. Oldfield, 1996) or to specific proxies and/or archives (e.g. pollen data: Sadori et al., 2007; lake records: Zolitschka et al., 2000), considering the entire Holocene or only a part of it (e.g. the mid-Holocene transition: Roberts et al., 2011; or the last two centuries: Diaz and Nanni, 2006).

This special issue of Climate of the Past brings together studies developed within the LAMA project. The LAMA ("Holocene changes in environment and climate, and histories of human societies in Central Mediterranean as reflected by Lakes and Marines records") project was funded for three years from 2008 to 2011 by the French ANR. It was hosted by the Maison des Sciences de l'Homme et de l'Environnement Ledoux (CNRS-USR3124, Besançon, France). Inspired by the pionier PALICLAS project (Oldfield, 1996), the LAMA project was based on a multi-proxy, multi-archive approach to reconstruct environmental and climatic changes during the Holocene in the Central Mediterranean. The geographical morphology of the Italian peninsula actually offers an exceptional opportunity to choose study sites along a north-south transect from the southern Alps in northern Italy to Sicily, and to couple lacustrine and marine archives (Fig. 1). The main original objectives and expected achievements of LAMA were to 


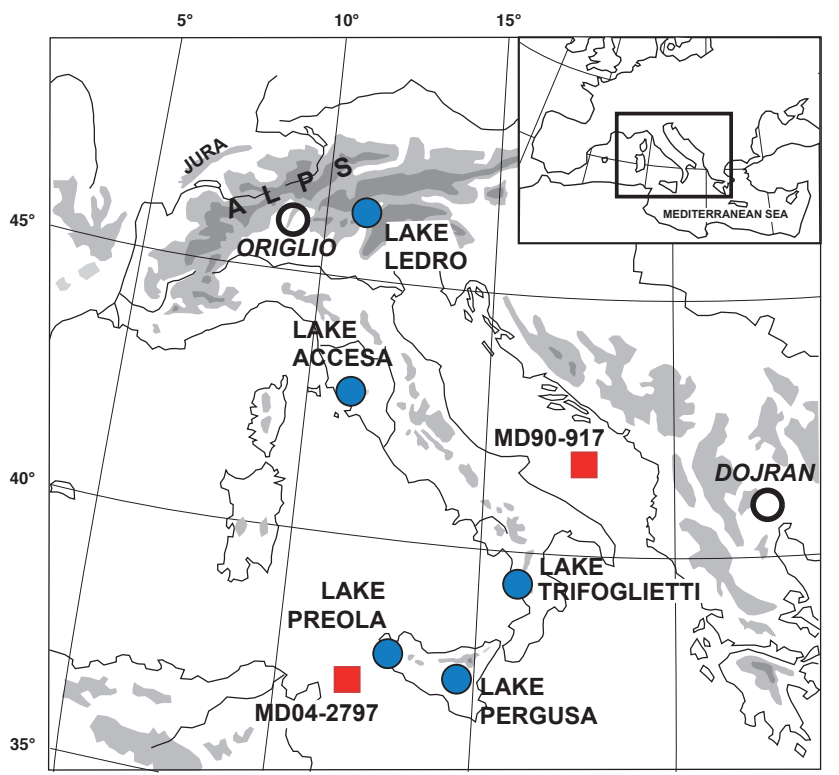

Fig. 1. Geographical location of the study sites corresponding to the contributions included in this special issue. Blue circles and red squares correspond to lake and marine records established within the LAMA project.

- provide high-resolution records to capture not only millennial trends but also centennial-scale events and possible abrupt changes;

- establish robust chronological controls for all the records (using both radiocarbon dates and tephra layers) to favour inter-regional correlations;

- develop an integrated multi-proxy approach using both biotic and abiotic indicators, to make the comparison between proxy data easier and to reconstruct seasonality, with a special focus on palaeohydrological changes which are a key factor for Mediterranean ecosystems and societies; and

- produce quantitative estimates of temperature and precipitation to give evidence of a possible latitudinal gradient in the Central Mediterranean during the Holocene.

The location of the study sites and the chronological spanning of the contributions gathered in this special issue are presented in Figs. 1 and 2. In addition to twelve studies directly supported by the LAMA project, this volume hosts two studies from sites belonging to or close to the Central Mediterranean, i.e. Lake Origlio in the northern Italy (Samartin et al., 2012) and Lake Dojran in Macedonia (Francke et al., 2013).

The first two papers focus on the Late Glacial-Holocene transition, i.e. the deglaciation period and point out a possible earlyness of climatic warming in southern Europe after the Last Glacial Maximum. Sea surface temperature records have been established by Sicre et al. (2013)

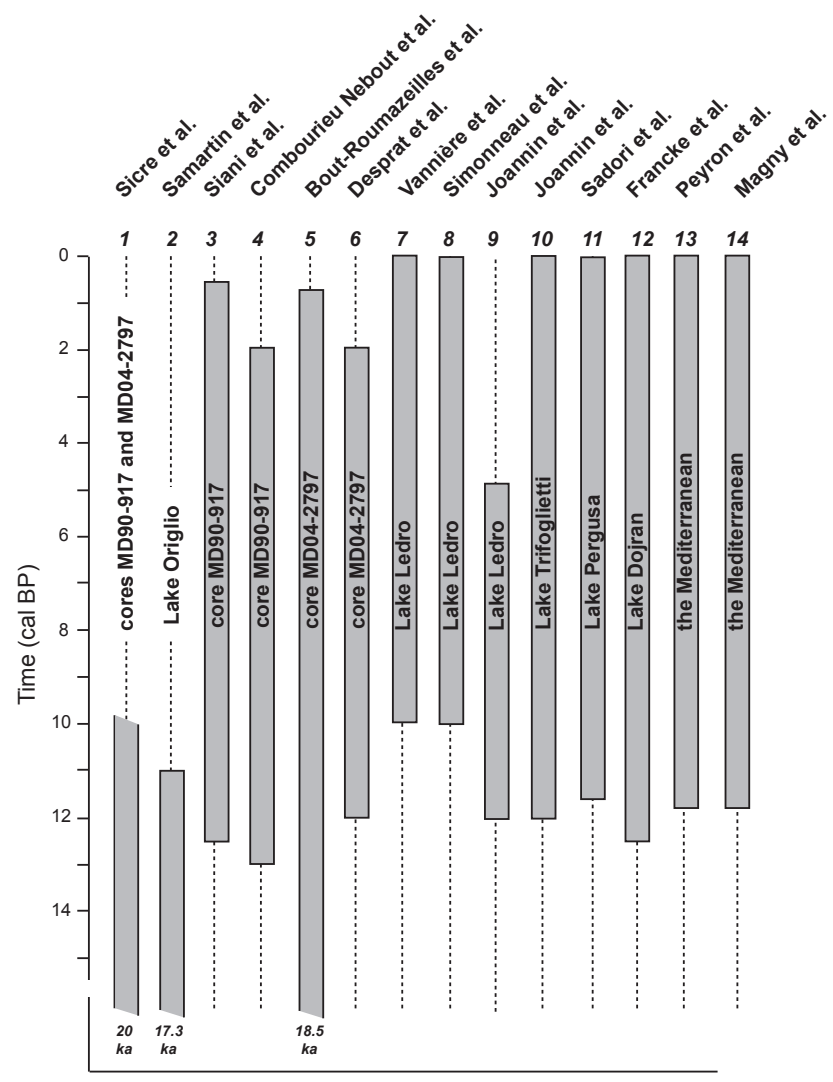

Fig. 2. Time windows documented by the fourteen contributions in this special issue.

from marine cores MD90-917 in the South Adriatic Sea (SAS) and MD04-2797 in the Siculo-Tunisian strait using alkenone palaeothermometry and planktonic foraminifera assemblages. The general picture which emerges from these two marine records is that of a general warming trend from ca. $17 \mathrm{ka}$ to the early Holocene, even if interrupted by cold events synchronous with the $\mathrm{H} 1$ event and the Greenland Stadial 1. It is worth noting that the chronological position and the magnitude of the reconstructed warming varies depending on the proxy used for the reconstruction and possible seasonal effects as discussed by Sicre et al. (2013). This first paper fully supports the results presented in the second contribution by Samartin et al. (2012). Using chironomidinferred July temperature estimates from Lake Origlio in northern Italy, Samartin et al. (2012) give evidence of a rather abrupt warming as early as $16500-16000$ cal BP consistent with an early reforestation in northern Italy (Ravazzi et al., 2012), as well as with sea-surface temperature records from the Tyrrhenian Sea (Cacho et al., 2001), speleothem records from Israel and northern Turkey (Bar-Matthews et al., 1999; Fleitmann et al., 2009).

Focussing on Holocene marine archives, the records established by Siani et al. (2013) and Combourieu Nebout et al. (2013) using abiotic and biotic indicators from marine 
core MD90-917 shed light on the Holocene millennial- and centennial-scale climate variability in South Adriatic Sea. Results reveal two contrasting palaeohydrological periods with a marked lowering of the salinity during the middle part of the Holocene (including the deposition of Sapropel 1), followed by a period of increasing salinity and dryness. Superimposed on these millennial trends, short-term centennial-scale events punctuated the entire Holocene with major events around $8.2 \mathrm{ka}$ (interruption of the Sapropel $1 \mathrm{de}-$ position) and ca. $7 \mathrm{ka}$. These short-term hydrological changes may be related to more intensive runoff of the Po River (particularly around $7 \mathrm{ka}$ ) and/or Apennine rivers (particularly during the second half of the Holocene) as well supported by clay data. Taken together, the results obtained from core MD90-917 are fully consistent with the general picture of the Holocene in the Mediterranean Basin and they give new insights about land-sea correlations. Thus, centennial-scale events marked by changes in the hydrology and/or in the vegetation cover suggest strong similarities and/or correlations not only with short-terms events recognised in the Central Mediterranean (Magny et al., 2013) but also, in particular through the influence of the Po River into the Adriatic Sea, with those identified at more northern latitudes in northern Italy and in the Alps.

In the Siculo-Tunisian Strait, the combination of mineralogical, grain-size, geochemical (Bout-Roumazeilles et al., 2013) and pollen (Desprat et al., 2013) data from core MD04-2797 allows to outline (1) a regional picture of the Holocene in the southernmost part of the Central Mediterranean, as well as (2) large-scale changes in atmospheric and marine circulations. The Bölling-Alleröd conditions are characterised by a dominance of the eolian part in the terrigenous supplies, with a major Saharan contribution, while the Younger Dryas correspond to proximal dust inputs highlighting intense regional eolian erosion and strong wind activity. The onset of the Holocene coincided with a major change in clay mineralogy and cristallinity which suggest a southward migration of dust provenance toward the Sahelian belt, as a result of a progressive development of the regional vegetation cover. During the interval $8600-5500 \mathrm{cal} \mathrm{BP}$, the sedimentological indicators reveal an enhanced riverine contribution reflecting an influence of the Nile River during Sapropel 1. Such a propagation of Nile River inputs until the SiculoTunisian Strait through intermediate water masses offers an additional illustration of enhanced precipitation in the northeast Africa (Revel et al., 2010) during the Sapropel 1 deposition. In contrast, the late Holocene shows a resuming of eolian dust with contribution from northern Sahel or southern Morocco, and drier climate conditions consistent with a decrease in the regional vegetation cover (Desprat et al., 2013).

The pollen study of core MD04-2797 by Desprat et al. (2013) fully supports the results obtained by Bout-Roumazeilles et al. (2013) from sedimentological markers. The domination of semi-desert plants mark arid conditions not only during the Bölling-Alleröd interstadial and the Greenland Stadial 1, but also during the early part of the Holocene until ca $10100 \mathrm{cal} \mathrm{BP}$, despite increasing temperature at that time. The interval $10100-6600 \mathrm{cal} \mathrm{BP}$ benefited from wetter conditions while increasing dryness from $6600 \mathrm{cal}$ BP onwards favoured Mediterranean plants. This general pattern of vegetation history is in agreement with lake-level data from south-central Mediterranean (Magny et al., 2011, 2013). Desprat et al. (2013) suggest that increasing moisture during $\mathrm{S} 1$ as reflected by changes in vegetation cover probably resulted from the increased melting of the Laurentide ice sheet between 10 and $6.8 \mathrm{ka}$ in conjunction with weak winter insolation to control the strength and position of the North Atlantic storm track. Superimposed on millennial trends, centennial-scale events marked by drier conditions (decline of tree pollen) appears to be in phase (1) with short-term climate reversals due to the deglaciation in the North Atlantic area, and (2) with cooling events observed in mid-European latitudes (Magny, 2013; Magny et al., 2013).

Regarding the lacustrine archives, the next three contributions deal with sedimentological and palynological data collected in Lake Ledro in Trentino, northern Italy. Using sediment markers, the contribution by Vannière et al. (2013) presents of flood frequency record established from deep cores in the Lake Ledro basin. It spans the last $10 \mathrm{ka}$. While the early and mid-Holocene periods show relatively low flood frequency, the late Holocene from ca. $4500 \mathrm{cal} \mathrm{BP}$ onwards is characterised by increasing flood frequency, in full agreement with the sediment sequence of neighbouring Lake Iseo which shows a strong increase in the sedimentation rate around $4500 \mathrm{cal} \mathrm{BP}$ (Lauterbach et al., 2012) and the beginning of the Neoglacial in the Central Mediterranean as supported by various palaeoclimatic records (Magny et al., 2009a; Zanchetta et al., 2012). The role of the climate as the main forcing factor in flood activity is supported by correlations with lake-level fluctuations along the Holocene: lakelevel rises coincided with increasing flood activity. Orbital changes and variations in solar activity appear to have been the main forcing factors of flood activity at Ledro, but since the Bronze age, increasing anthropogenic activities may partially explain the increasing amplitude of floods.

Combining sediment studies on deep cores from Lake Ledro and on soil and river-bed samples, Simonneau et al. (2013) establish a picture of the Lake Ledro catchment area in relation to changes in climate conditions and land use. During the early Holocene, the progressive afforestation led to a stabilization of the soils only interrupted by the $8.2 \mathrm{ka}$ event responsible for a strong soil erosion. The midHolocene corresponds to both a low soil erosion in the catchment area and a higher algal production in the lake basin. During the late Holocene, after ca. $4500 \mathrm{cal} \mathrm{BP}$, wetter climate conditions and human activities drastically increase soil erosion rates. This study highlights how changes in land use combined with climate variations may have substantial impact on the soil erosion and the pedogenesis in sensitive highelevated areas. 
The contribution by Joannin et al. (2013) presents a welldated high-resolution record for the early to mid-Holocene at Ledro, i.e. before the development of a strong human impact from ca. $4100 \mathrm{cal} \mathrm{BP}$ onwards (Bronze age lake dwellings on the lake shores; Magny et al., 2009a). Comparison of pollen data from Lake Ledro with pollen records from northern Italy (to the north of the Po Valley) suggest that, during the Late Glacial-early Holocene transition, the start of the continuous representation of the fir (Abies) and the development of larch (Larix) follow an altitudinal gradient, with an increasing time-lag in response to higher elevation. Changes in pollen assemblages give evidence of centennial-scale cold reversals around $11000,10200,9300$ and $8200 \mathrm{cal} \mathrm{BP}$ in possible relation with deglacial events in the North Atlantic area. The $8.2 \mathrm{ka}$ event favoured the extension of the fir while the beech (Fagus) shows a bi-phased expansion around 7500 6000 and 5300-4000 cal BP probably in response to orbital forcing rather than to human influence.

To more southerly latitudes, the papers by Joannin et al. (2012) and Sadori et al. (2013) establish two new pollen records from terrestrial sites in the south-central Mediterranean. Lake Trifoglietti in Calabria, southern Italy, provides a well-dated high-resolution pollen record, which reveals only poor imprints of human impact probably due to the relatively high elevation of the site, i.e. $1048 \mathrm{~m}$ a.s.l. (Joannin et al., 2012). In the early part of the Holocene, i.e. until ca. $11000 \mathrm{cal} \mathrm{BP}$, pollen data suggest that the site was above the timberline. In contrast to sites from the Northern Apennines (e.g. Lowe and Watson, 1993; Watson, 1996), a comparison with other sites from the south-central Mediterranean gives evidence of an increasing time lag towards the south for the afforestation due to persistent dry conditions during the early part of Holocene. This is consistent with regional lakelevel data (Magny et al., 2011). A ratio between hygrophilous and terrestrial taxa gives evidence of a maximum of humidity between 9400 and ca. $6200 \mathrm{cal}$ BP (i.e. broadly during the Sapropel 1 deposition). In addition, in agreement with the contributions of Desprat et al. (2013) and Combourieu Nebout et al. (2013), changes in pollen assemblages point to centennial-scale dry events in response to cooling events recognised in the North Atlantic area and/or in the Central Mediterranean.

Recent investigations at Lake Pergusa offered the opportunity to establish a new pollen record spanning the last seven millennia in central Sicily with a particularly high resolution for the last $3000 \mathrm{yr}$. Quantitative estimates of climatic parameters inferred from pollen data using MAT and WA-PLS display a trend towards lower precipitation and higher temperature throughout the last three millennia, interrupted by centennial-scale events with cooler and wetter climatic conditions, more particularly around $2600-2000 \mathrm{cal} \mathrm{BP}$ and during the Little Ice Age. As discussed by Magny et al. (2013), this suggests fluctuations of the latitudinal limit between the two Holocene palaeohydrological sectors distinguished in the Central Mediterranean. Finally, the pollen data obtained at Pergusa which (1) show a strong imprint of human activities and (2) appear to be consistent with palaeoclimatic data from the literature, point out a possible synergy between human activities and climate in shaping the Sicilian landscape.

Close to the Central Mediterranean, in the Balkan region, a $7 \mathrm{~m}$ long core from Lake Dojran at the border between Macedonia and Greece provided an interesting record of environmental and climatic change over the last $12500 \mathrm{yr}$. Regarding the Holocene, a combination of various sedimentological markers and a robust age model led Francke et al. (2013) to infer that more humid conditions and probable higher lakelevel conditions coincided with the formation of Sapropel 1, with increased runoff in the catchment area. This phase was interrupted by a return to drier and cooler conditions (lakelevel lowering) during the $8.2 \mathrm{ka}$ event. Overall, the period between 7900 and $4300 \mathrm{cal} \mathrm{BP}$ is characterised by relatively stable conditions, however, somewhat dryer conditions and a slightly reduced lake level were reconstructed for the period after $6000 \mathrm{cal} \mathrm{BP}$. Intensive human induced erosion developed in the catchment since $2800 \mathrm{cal} B$. These results suggest that, despite a relatively northern latitudinal location (around $41^{\circ} \mathrm{N}$ ), Lake Djoran may have been included in the southern palaeohydrological sector in the Mediterranean, with an apparent contrast to lake-level data obtained from littoral cores at Lake Maliq (ca. $40^{\circ} \mathrm{N}$ ) in Albania (Magny et al., 2009b). As an alternative interpretation, given the proximity between the two lakes (less than $100 \mathrm{~km}$ ) and taking into account that the lake-level interpretation of Lake Dojran has been inferred from sedimentological markers in a deep core, this apparent opposition between records may reflect differences in the methods of reconstruction and/or the seasonality as pointed out by Magny et al. (2012b).

The last two papers of this special issue endeavour to establish palaeoclimatic syntheses for the Holocene in the Central Mediterranean. Lake-level records from the Italian peninsula and Sicily have suggested a north-south climatic partition during the Holocene in the Central Mediterranean with respect to the precipitation seasonality (Magny et al., 2012b). Peyron et al. (2013) test this working-hypothesis on the basis of pollen-inferred quantitative estimates and a multi-method approach. They confirm the pattern of contrasting mid-Holocene summer precipitation regimes, with minima (maxima) of summer precipitation and lake levels to the north (south) of ca. $40^{\circ} \mathrm{N}$. Summer temperature show a similar partition for the mid-Holocene in the Central Mediterranean, with warmer (cooler) conditions to the north (south). A comparison with results obtained from marine cores in the Aegean Sea suggest that, during the Holocene, similar climatic trends and north-south gradients as those reconstructed in the Central Mediterranean may have characterised the eastern Mediterranean.

Finally, the paper by Magny et al. (2013) focuses on Holocene palaeohydrological changes in the Central Mediterranean, using mainly lake-level, charcoal and pollen data collected within the LAMA project. It points 
to north-south contrasts which operated during the entire Holocene at both millennial- and centennial-scales. In agreement with the fourth ambiguity addressed by Tzedakis (2007), results reveal that, in addition to the influence of the Nile discharge reinforced by the African monsoon, the deposition of Sapropel 1 has been favoured by an increase (1) in winter precipitation in the northern Mediterranean borderlands, and (2) in winter and summer precipitation in the southern Mediterranean. Moreover, this contribution tries to replace the palaeohydrological changes reconstructed in the Central Mediterranean into a large-scale context. Comparisons with other palaeohydrological/palaeoclimatic records from North Africa to Scandinavia suggest that palaeohydrological changes in the Central Mediterranean developed in response to a combination of orbital, ice-sheet and solar forcing factors. They also point to possible key influences of (1) the Latitudinal Temperature Gradient (Davis and Brewer, 2009) to explain the varying position of the ITCZ and westerlies, and (2) changes in patterns of general atmospheric circulation (such as NAO-type circulation, EAWR, North Sea-Caspian) to explain contrasting palaeohydrological patterns around the Mediterranean Basin and in Europe.

Considered as a whole, the contributions gathered in this special issue invite to formulate various remarks relative to further investigations in the perspective of a better understanding of Holocene environmental and climatic changes in the Mediterranean area as follows.

- The improvement of the time control appears to be the first prerequisite to develop fruitful cross-correlations between records at regional and inter-regional scales. As discussed in many previous studies, this question of the time control is a crucial point to, for instance, test the possibility of (1) forcing factors operating at centennial to decadal scales, (2) atmospheric circulation patterns (such as NAO, EAWR, or North Sea-Caspian) which imply comparisons between records from distant areas, or (3) interactions between past trajectories of ecosystems and societies.

- As a complement of a robust and precise time control, there is a need of high-resolution palaeoenvironmental/palaeoclimatic records to capture short-term events and abrupt changes, and to give evidence of possible nonlinear responses (tipping points) of the ecosystems and climate mechanisms to progressive changes in (natural and/or anthropogenic) forcing factors.

- There is a growing evidence that the reconstruction of the seasonality (temperature, precipitation) is a key point not only for a better understanding of the trajectories of Mediterranean ecosystems and societies, but also for the identification of the climatic forcing factors/mechanisms behind the reconstructed palaeoenvironmental changes. This is more particularly true for the
Mediterranean area characterised by a strong opposition between summer and winter seasons, with specific climate mechanisms depending on the season considered. In addition, the reconstruction of the seasonality may help to solve apparent contradictions between palaeoclimatic records depending on the proxy used for the reconstruction (Sarikaya et al., 2008; Magny et al., 2012b, 2013; Milner et al., 2012; Sicre et al., 2013).

- As a consequence of the previous point, further investigations should systematically privilege integrated multi-proxy approaches to facilitate comparisons between data and their possible interpretations in terms of seasonality (Sicre et al., 2013). In addition, integrated multi-proxy approaches are of interest to reconstruct the different components (abiotic and biotic) of ecosystems as illustrated by the contributions relative to Lakes Dojran and Ledro (Francke et al., 2013; Joannin et al., 2013; Simonneau et al., 2013; Vannière et al., 2013) or to marine cores MD90-917 (Siani et al., 2013; Combourieu Nebout et al., 2013) and MD04-2797 (Desprat et al., 2013).

- Another key point is the development of quantitative palaeoclimatic records using various independent methods for the reconstruction (e.g. Samartin et al., 2012; Peyron et al., 2013). This approach allows to give evidence of possible biases due to methodological limits and/or to environmental/biological conditions (e.g. Sicre et al., 2013).

- Model/data comparisons should be developed and improved to help solving ambiguities or apparent contradictions around the identification of climatic changes at a regional scale as well as the reconstruction of past atmospheric general circulation patterns. Thus, in order to explain an increased winter precipitation during the $10000-7000 \mathrm{cal}$ BP interval in the Mediterranean area, Desprat et al. (2013) pointed to a possible southern location of the mid-latitudes jet, strengthening the Mediterranean cyclogenesis, in agreement with model simulations in response to a weaker boreal winter insolation (Brayshaw et al., 2011) and to a rapid LIS melting associated with a suppression of the deep convection in the Labrador Sea and a cooling the eastern North Atlantic (Carlson et al., 2008). In contrast, in agreement with other models simulations (Lézine et al., 2011), Magny et al. (2013) suggest that the mid-Holocene interval of maximum humidity in the Mediterranean corresponded to a positive NAO-like circulation pattern: as a result from a weaker Latitudinal Temperature Gradient (Davis and Brewer, 2009), the westerlies could have reached more northerly latitudes bringing milder and wetter climatic conditions to northern Europe.

- There is a need of large-scale projects based on a careful selection of study sites in relation with well-defined 
objectives, for instance to test the possible impact of climatic mechanisms or types of atmospheric circulation such as NAO (e.g. Lamy et al., 2006; Magny et al., 2013), and climate gradients and/or forcing factors using sites along north-south/west-east transects. As far as possible, these large-scale projects should develop homogeneous methods to facilitate comparisons between records and reinforce the robustness of interpretations.

- Future investigations also should favour projects that integrate studies of marine and terrestrial (lacustrine) cores to develop land-sea correlations in the perspective of more global reconstructions of past environmental and climatic changes in the Mediterranean area. Such consortiums should encourage partnerships between marine and continental communities of scientists.

- A last but crucial point in the reconstruction of Holocene environmental changes in the circumMediterranean area is the development of data relative to the history of societies for a better understanding of their past interactions with environment. Pollen data provide a first picture of possible human impact (e.g. deforestation, cultivation of Cerealia, Olea). However, there is today an urgent need of additional archaeological (historical) data able (1) to document more precisely the agricultural practices and their variations in space and time throughout the Mediterranean area, and (2) to assess the human pressure on environment both in terms of technology and demography. The stake is a more rigorous evaluation of what is suspected behind the so-called "human impact" in terms of (i) chain of processes and (ii) quantification of them. Such systematic approaches should favour the development of better formalized methods (e.g. model experiments, multivariate numerical analyses) to assess past environment/societies interactions.

Our sincere thanks to the French "Agence Nationale de Recherche" and to the "Maison des Sciences de l'Homme et de l'Environnement Ledoux" (CNRS-USR3124, Besançon, F. Favoury, I. Mouret) which, respectively, funded and hosted the LAMA project, as well as to INEE (dir. S. Thiébault) and INSU (dir. J. F. Stéphan) of the French CNRS, to MSHE Ledoux (CNRS-USR3124, Besançon), and to Laboratoire Chrono-Environnement (CNRS-UMR6249, D. Gilbert) which sponsored the publication of this special issue. Thanks to the CNRS that has supported part of the marine researches of the LAMA project. This is LSCE contribution no. 4589.

\section{References}

Bar-Matthews, M., Ayalon, A., Kaufman, A., and Wasserburg, G. J.: The eastern Mediterranean paleoclimate as a reflection of regional events: Soreq cave, Israel, Earth Planet. Sc. Lett., 166, 85-95, 1999.

Bout-Roumazeilles, V., Combourieu-Nebout, N., Desprat, S., Siani, G., Turon, J.-L., and Essallami, L.: Tracking atmospheric and riverine terrigenous supplies variability during the last glacial and the Holocene in central Mediterranean, Clim. Past, 9, 10651087, doi:10.5194/cp-9-1065-2013, 2013.

Brayshaw, D. J., Rambeau, C. M. C., and Smith, S. J.: Changes in mediterranean climate during the holocene: Insights from global and regional climate modelling, Holocene, 21, 15-31, 2011.

Cacho, I., Grimalt, J. O., Canals, M., Sbaffi, L., Shackleton, N. J., Schönfeld, J., and Zahn, R.: Variability of the Western Mediterranean sea surface temperature during the last 25000 years and its connection with the Northern Hemisphere climatic changes, Paleoceanography, 16, 40-52, 2001.

Carlson, A. E., Legrande, A. N., Oppo, D. W., Came, R. E., Schmidt, G. A., Anslow, F. S., Licciardi, J. M., and Obbink, E. A.: Rapid early Holocene deglaciation of the Laurentide ice sheet, Nat. Geosci., 1, 620-624, 2008.

Catto, N.: Quaternary of the Mediterranean basin and Western Asia: marine and terestrial processes and palaeoenvironments, Quatern. Int., 140/141, 1-4, 2005.

Combourieu-Nebout, N., Peyron, O., Bout-Roumazeilles, V., Goring, S., Dormoy, I., Joannin, S., Sadori, L., Siani, G., and Magny, M.: Holocene vegetation and climate changes in central Mediterranean inferred from a high-resolution marine pollen record (Adriatic Sea), Clim. Past Discuss., 9, 1969-2014, doi:10.5194/cpd-9-1969-2013, 2013.

Davis, B. A. S. and Brewer, S.: Orbital forcing and role of the latitudinal insolation/temperature gradient, Clim. Dynam., 32, 143165, 2009.

Desprat, S., Combourieu-Nebout, N., Essallami, L., Sicre, M. A., Dormoy, I., Peyron, O., Siani, G., Bout Roumazeilles, V., and Turon, J. L.: Deglacial and Holocene vegetation and climatic changes in the southern Central Mediterranean from a direct land-sea correlation, Clim. Past, 9, 767-787, doi:10.5194/cp-9767-2013, 2013.

Diaz, R. H. and Nanni, T.: Historical reconstruction climate variability and change in Mediterranean regions, Il Nuovo Cimento, 29, 1-2, 2006.

Fleitmann, D., Cheng, H., Badertscher, S., Edwards, R. L., Mudelsee, M., Göktürk, O. M., Fankhauser, A., Pickering, R., Raible, C. C., Matter, A., Kramers, J., and Tüysüz, O.: Timing and climatic impact of Greenland interstadials recorded in stalagmites from northern Turkey, Geophys. Res. Lett., 36, L19707, doi:10.1029/2009GL040050, 2009.

Francke, A., Wagner, B., Leng, M. J., and Rethemeyer, J.: A Late Glacial to Holocene record of environmental change from Lake Dojran (Macedonia, Greece), Clim. Past, 9, 481-498, doi:10.5194/cp-9-481-2013, 2013.

Joannin, S., Brugiapaglia, E., de Beaulieu, J.-L., Bernardo, L., Magny, M., Peyron, O., Goring, S., and Vannière, B.: Pollenbased reconstruction of Holocene vegetation and climate in southern Italy: the case of Lago Trifoglietti, Clim. Past, 8, 19731996, doi:10.5194/cp-8-1973-2012, 2012. 
Joannin, S., Vannière, B., Galop, D., Peyron, O., Haas, J. N., Gilli, A., Chapron, E., Wirth, S. B., Anselmetti, F., Desmet, M., and Magny, M.: Climate and vegetation changes during the Lateglacial and early-middle Holocene at Lake Ledro (southern Alps, Italy), Clim. Past, 9, 913-933, doi:10.5194/cp-9-913-2013, 2013.

Lamy, F., Arz, H. W., Bond, G. C., Bahr, A., and Pätzold, J.: Multicentennial-scale hydrological changes in the Black Sea and northern Red Sea during the Holocene and the Arctic/North Atlantic Oscillation, Paleoceanography, 21, PA1008, doi:10.1029/2005PA001184, 2006.

Lauterbach, S., Chapron, E., Brauer, A., Hüls, M., Gilli, A., Arnaud, F., Piccin, A., Nomade, J., Desmet, M., von Grafenstein, U., and Decklakes Participants: A sedimentary record of Holocene surface runoff events and earthquake activity from Lake Iseo (Southern Alps, Italy), Holocene, 22, 749-760, 2012.

Lézine, A. M., Hély, C., Grenier, C., Braconnot, P., and Krinner, G.: Sahara and Sahel vulnerability to climate changes, lessons from Holocene hydrological data, Quaternary Sci. Rev., 30, 30013012, 2011.

Lowe, J. J. and Watson, C.: Lateglacial and early Holocene pollen stratigraphy of the northern Apennines, Italy: a contribution to "North Atlantic seaboard programme" of IGCP-253, "Termination of the Pleistocene", Quaternary Sci. Rev., 12, 727-738, 1993.

Magny, M.: Orbital, ice-sheet, and possible solar forcing of Holocene lake-level fluctuations in west-central Europe, A comment on Blezicher (2013), Holocene, doi:10.1177/0959683613483627, in press, 2013.

Magny, M., Galop, D., Bellintani, P., Desmet, M., Didier, J., Haas, J. N., Martinelli, N., Pedrotti, A., Scandolari, R., Stock, A., and Vannière, B.: Late-Holocene climatic variability south of the Alps as recorded by lake-level fluctuations at Lake Ledro, Trentino, Italy, Holocene, 19, 575-589, 2009a.

Magny, M., Vannière, B., Zanchetta, G., Fouache, E., Touchais, G., Petrika, L., Coussot, C., Walter-Simonnet, A. V., and Arnaud, F.: Possible complexity of the climatic event around 4300$3800 \mathrm{cal} \mathrm{BP}$ in the central and western Mediterranean, Holocene, 19, 823-833, 2009b.

Magny, M., Vannière, B., Calo, C., Millet, L., Leroux, A., Peyron, O., Zanchetta, G., La Mantia, T., and Tinner, W.: Holocene hydrological changes in south-western Mediterranean as recorded by lake-level fluctuations at Lago Preola, a coastal lake in southern Sicily, Italy, Quaternary Sci. Rev., 30, 2459-2475, 2011.

Magny, M., Joannin, S., Galop, D., Vannière, B., Haas, J. N., Bassetti, M., Bellintani, P., Scandolari, R., and Desmet, M.: Holocene palaeohydrological changes in the northern Mediterranean borderlands as reflected by the lake-level record of Lake Ledro, northeastern Italy, Quaternary Res., 77, 382-396, 2012a.

Magny, M., Peyron, O., Sadori, L., Ortu, E., Zanchetta, G., Vannière, B., and Tinner, W.: Contrasting patterns of precipitation seasonality during the Holocene in the south- and northcentral Mediterranean, J. Quaternary Sci., 27, 494-502, 2012 b.

Magny, M., Combourieu Nebout, N., de Beaulieu, J. L., BoutRoumazeilles, V., Colombaroli, D., Desprat, S., Francke, A., Joannin, S., Peyron, O., Revel, M., Sadori, L., Siani, G., Sicre, M. A., Samartin, S., Simonneau, A., Tinner, W., Vannière, B., Wagner, B., Zanchetta, G., Anselmetti, F., Brugiapaglia, E., Chapron, E., Debret, M., Desmet, M., Didier, J., Essallami, L., Galop, D.,
Gilli, A., Haas, J. N., Kallel, N., Millet, L., Stock, A., Turon, J. L., and Wirth, S.: North-south palaeohydrological contrasts in the central Mediterranean during the Holocene: tentative synthesis and working hypotheses, Clim. Past Discuss., 9, 1901-1967, doi:10.5194/cpd-9-1901-2013, 2013.

Milner, A. M., Collier, R. E. L., Roucoux, K. H., Müller, U. C., Pross, J., Kalaitzidis, S., Christanis, K., and Tzedakis, P. C.: Enhanced seasonality of precipitation in the Mediterranean during the early part of the Last Interglacial, Geology, 40, 919-922, doi:10.1130/G33204.1, 2012.

Oldfield, F.: PALICLAS: the partnership, its perspectives and goals, Memorie dell' Istituto Italiano di Idrobiologia, Int. J. Limnol., 55, 7-16, 1996.

Perez-Obiol, R., Jalut, G., Julià, R., Pèlachs, A., Iriarte, M. J., Otto, T., and Hernandez-Beloqui, B.: Mid-Holocene vegetation and climatic history of the Iberian Peninsula, Holocene, 21, 75-94, 2011.

Peyron, O., Magny, M., Goring, S., Joannin, S., de Beaulieu, J.L., Brugiapaglia, E., Sadori, L., Garfi, G., Kouli, K., Ioakim, C., and Combourieu-Nebout, N.: Contrasting patterns of climatic changes during the Holocene across the Italian Peninsula reconstructed from pollen data, Clim. Past, 9, 1233-1252, doi:10.5194/cp-9-1233-2013, 2013.

Pinardi, N. and Masetti, E.: Variability of the large scale general circulation of the Mediterranean Sea from observations and modelling: a review, Palaeogeogr. Palaeocl., 158, 153-173, 2000.

Ravazzi, C., Badino, F., Marsetti, D., Patera, G., and Reimer, P. J.: Glacial to paraglacial history and forest recovery in the Oglio glacier system (Italian Alps) between 26 and $15 \mathrm{ka} \mathrm{cal} \mathrm{BP,} \mathrm{Qua-}$ ternary Sci. Rev., 58, 146-161, 2012.

Revel, M., Ducassou, E., Grousset, F., Bernasconi, S. M., Migeon, S., Revillon, S., Mascle, J., Murat, A., Zaragosi, S., Bosch, D. 100000 years of African monsoon variability recorded in sediments of the Nile margin, Quaternary Sci. Rev., 29, 1342-1362, 2010.

Roberts, N., Kuzucuoglu, C., and Karabiyikoglu, M.: The late Quaternary in the eastern Mediterranean, Quaternary Sci. Rev., 18, 497-499, 1999.

Roberts, N., Meadows, M. E., and Dodson, J. R.: The history of mediterranean-type environments: climate, culture and landscape, Holocene, 11, 631-634, 2001

Roberts, N., Brayshaw, D., Kuzucuoglu, C., Perez, R., and Sadori, L.: The mid-Holocene climatic transition in the Mediterranean: causes and consequences, Holocene, 21, 3-14, 2011.

Sadori, L., Pérez-Obiol, R., and Bittmann, F.: Introduction to the special issue "Evolution of the landscape and climate in the Mediterranean ecosystem", Veg. Hist. Archaeobot., 16, p. 221, 2007.

Sadori, L., Ortu, E., Peyron, O., Zanchetta, G., Vannière, B., Desmet, M., and Magny, M.: The last 7 millennia of vegetation and climate changes at Lago di Pergusa (central Sicily, Italy), Clim. Past Discuss., 9, 2059-2094, doi:10.5194/cpd-92059-2013, 2013.

Samartin, S., Heiri, O., Lotter, A. F., and Tinner, W.: Climate warming and vegetation response after Heinrich event 1 (1670016000 cal yr BP) in Europe south of the Alps, Clim. Past, 8, 1913-1927, doi:10.5194/cp-8-1913-2012, 2012. 
Sarikaya, M. A., Zreda, M., Çiner, A., and Zweck, C.: Cold and wet Last Glacial Maximum on Mount Sandiras, SW Turkey, inferred fromcosmogenic dating and glacier modeling, Quaternary Sci. Rev., 27, 769-780, 2008.

Siani, G., Magny, M., Paterne, M., Debret, M., and Fontugne, M.: Paleohydrology reconstruction and Holocene climate variability in the South Adriatic Sea, Clim. Past, 9, 499-515, doi:10.5194/cp-9-499-2013, 2013.

Sicre, M.-A., Siani, G., Genty, D., Kallel, N., and Essallami, L.: Seemingly divergent sea surface temperature proxy records in the central Mediterranean during the last deglaciation, Clim. Past, 9, 1375-1383, doi:10.5194/cp-9-1375-2013, 2013.

Simonneau, A., Chapron, E., Vannière, B., Wirth, S. B., Gilli, A., Di Giovanni, C., Anselmetti, F. S., Desmet, M., and Magny, M.: Mass-movement and flood-induced deposits in Lake Ledro, southern Alps, Italy: implications for Holocene palaeohydrology and natural hazards, Clim. Past, 9, 825-840, doi:10.5194/cp-9825-2013, 2013.

Solomon, S., Qin, D., Manning, M., Marquis, M., Avery, K., Tigno, M., Mille, H., and Che, Z.: Climate Change 2007: The Physical Science Basi. Contribution of Working Group I to the Fourth Assessment Report of the Intergovernmental Panel on Climate Chang, Cambridge University Pres, Cambridge, 2007.
Tzedakis, P. C.: Seven ambiguities in the Mediterranean palaeoenvironmental narrative, Quaternary Sci. Rev., 26, 2042-2066, 2007.

Vannière, B., Magny, M., Joannin, S., Simonneau, A., Wirth, S. B., Hamann, Y., Chapron, E., Gilli, A., Desmet, M., and Anselmetti, F. S.: Orbital changes, variation in solar activity and increased anthropogenic activities: controls on the Holocene flood frequency in the Lake Ledro area, Northern Italy, Clim. Past, 9, 1193-1209, doi:10.5194/cp-9-1193-2013, 2013.

Watson, C.: The vegetational history of the northern Apennines, Italy: information from three new sequences and a review of regional vegetation change, J. Biogeogr., 23, 805-841, 1996.

Zanchetta, G., Giraudi, C., Sulpizio, R., Magny, M., Drysdale, R. N., and Sadori, L.: Constraining the onset of the Holocene "Neoglacial" over the central Italy using tephra layers, Quaternary Res., 78, 236-247, 2012.

Zolitschka, B., Wulf, S., and Negendank, J. F. W.: CircumMediterranean lake records as archives of climatic and human history, Quatern. Int., 73/74, 1-5, 2000. 